\title{
Har världshistorien ett kön? Familj och släkt i värIdspolitikens mitt
}

Maria Sjöberg

Göteborgs universitet

maria.sjoberg@history.gu.se

\author{
Key-words \\ Gender \\ world history \\ family \\ dynastic thinking \\ homosociality \\ household
}




\begin{abstract}
In recent decades, gender perspectives have been adopted and elaborated in almost all research areas of history, apart from world history. A review of articles published in the Journal of World History during 2001-13 demonstrates a general pattern of gender blindness in the journal, with a few important exceptions. Several explanations for why world history neglects gender history are examined in this article. First, it has been claimed that world history has a strong materialist tradition, while gender historians work mostly with cultural perspectives. However, the articles in the Journal of World History show that world history is not unfamiliar with cultural issues or methodologies. Secondly, gender historians emphasize the complexity of gender relations, which do not accord well with prevailing explanations within world history that stress macro theories and general patterns. Thirdly, gender historians concentrate their research on women in their own countries, and this is of minor interest to scholars of world history. Fourthly, the absence of women and gender relations in writing and teaching on world history reflects the fact that almost every society in world history has had a gender order that discriminates against women in favour of men. What is lacking is a consciousness of this order. This opinion is easy to agree with, but it does not suggest ways of improving the gender consciousness of world historians. Fifthly, one opinion stresses that most women in history have lived their lives in families, while families do not play an important role in world history. This opinion relies on a view of gender history as exclusively women's history. In order to emphasize and clarify gender as a structuring principle at the general level of societies, this article ends with an overview of a similarity of significance in almost all early modern political regencies. Dynastic thinking was established all over the world, from principalities to empires, and was everywhere constructed in terms of imagined family and kinship relations with superior masculinity and subordinated femininity. How can research in world history overlook this world-wide structure?
\end{abstract}


Sedan 1970-talets socialhistoriska uppsving har den könshistoriska forskningen vuxit lavinartat och är numera en väl integrerad aspekt i historieskrivningen. Även om kön i flera studier uppfattas som detsamma som kvinnor, och därmed inte utnyttjas fullt ut som den maktanalyserande kategori det skulle kunna vara, måste man säga att genomslaget för könshistoria är stort. Slutsatsen gäller dock inte för alla historiska inriktningar. Granskar man saken närmare framgår nämligen att könshistoriska perspektiv inte är särskilt framträdande i de världshistoriska översikter som bland annat används i undervisning på högskola och universitet (Sjöberg, 2012). Studenter som läser kronologiskt upplagda översiktskurser möter därmed ett förflutet som i stort sett framställs som något könsneutralt. Av tidigare diskussion att döma, tycks också världshistorisk forskning präglas av motsvarande könsblindhet. I den amerikanske historikern Patrick Mannings genomgång av den världshistoriska forskningens framväxt och utveckling konstateras exempelvis att: "World history, especially as a history of great states and long-distance trade, included little recognition of gender and little space for women" (Manning, 2003, s. 208). Sedan början på 2000-talet, alltså då Manning gjorde sin lägesbedömning, har läget visserligen förändrats något (t. ex. Smith, 2004-2005; Wiesner-Hanks 2011). Fortfarande - om man får tro senare inlägg i debatten - förbiser världshistorisk forskning i hög grad könsliga aspekter på det förflutna.

Varför är det så? Är kön av mindre relevans för världshistorisk forskning än andra inriktningar? I de senaste årens diskussion föreslås flera tänkbara orsaker, som tas upp utförligare längre fram. Mot denna bakgrund är avsikten i det följande att försöka gå vidare genom att visa hur kön, definierat som en samhälleligt strukturerande maktordning, kan vara till gagn i studier om världens historia. Allra först ges dock en bakgrund. Därefter redogörs för diskussionens huvuddrag. Sedan prövas om aktuell världshistorisk forskning verkligen är så ointresserad av könsliga perspektiv som debatten ger intryck av. Med utgångspunkt $\mathrm{i}$ hur imperier och stormakter generellt har konstruerat det politiska regentskapet visas slutligen hur kön som analytisk kategori faktiskt kan bidra till fördjupade förklaringar och sammanhang, även i världshistorisk forskning.

\section{Kultur och värIdshistoria}

I likhet med historieforskningen i stort har könshistorisk forskning genomgått stora förändringar sedan dess uppsving på 1970-talet (Sjöberg, 2001). Då var könshistoria detsamma som kvinnoforskning och inriktad på att synliggöra glömda men historiskt betydelsefulla kvinnor. I samband med en samtidig socialhistorisk expansion blev också kön en variabel (bland flera) i undersökningar som intresserade sig för socioekonomiska villkor i det förflutna. Oavsett infallsvinkel var maktrelationer mellan och inom kön ett ledmotiv. Könshistorien har sedan dess utvecklats àt flera olika håll: queer, intersektionalitet, materialitet är bara några av de många aspekter som följt av bland andra poststrukturalistiska och postkoloniala influenser. Maktfrågor är dock alltjämt centrala. I den spänning som hela tiden har funnits - och fortfarande finns - mellan essentialistiska och konstruktivistiska tolkningar, där bland annat frågor om vad som är naturligt respektive kulturellt betingat ständigt omprövas, har således kulturella perspektiv kommit att dominera. Könshistoriens teoriutveckling sammanfaller i så måtto med historieforskningens generella intresseförskjutning från materiella till kulturella villkor. I de sistnämnda aktualiseras det förflutnas mångdimensionella karaktär bland annat utifrån symboliska och lingvistiska aspekter. Där är det dessutom väsentligare att på djupet kontextuellt förstå historiska processer än att peka på bestämda orsakssamband (Sjöberg, 2007).

Den vikt vid kulturella faktorer som historieforskningen allmänt anlägger är dock inte lika påtaglig i världshistoriska översiktsverk. I exempelvis antropologen Jared Diamonds studie 
om mänsklighetens historia de senaste tusentals åren är syftet visserligen motiverat av socialt och politiskt aktuella frågor; med hjälp av historiska perspektiv på mänsklighetens historia vill han söka orsakerna bakom världens alltmer ojämlika förhållanden. Men det är inte könsligt arrangerade orättvisor som är i fokus, och heller inte ojämlika klassförhållanden, utan fördelningen av materiella resurser mellan världens länder och kontinenter. De faktorer Diamond lyfter fram som särskilt betydelsefulla bakom ekonomisk och politisk tillväxt kan sammanfattas i naturgeografiska förutsättningar. Konkret handlar det om förutsättningar för utbredningen av grödor och teknologi inom och mellan kontinenter, samt om kontinenternas geografiska och befolkningsmässiga storlek (Diamond, 2008 , s. 422-424). Diamond arbetar tvärvetenskapligt över stora geografiska ytor. Hans betoning på naturgeografiska faktorer innebär förstås att människors kulturella villkor hamnar i skymundan, och att kontinenternas inre förhållanden homogeniseras. Även arkeologen Ian Morris som, i likhet med Diamond, söker historisk belysning på ekonomiskt och politiskt aktuella förhållanden, nämligen västvärldens nuvarande men kanske tillfälliga ekonomiska dominans, framhåller naturgeografiska faktorer. Morris konstruerar en sorts index som mäter resurstillgång och resursanvändning $i$ vagt definierade områden som benämns öst och väst, vilka sedan jämförs över tid. Tonvikten ligger på kvantifierbara data och i dessa mätningar tillmäts kulturella faktorer och olikheter en underordnad eller obefintlig roll. Om till exempel den industriella revolutionen konstaterar Morris:

Given enough time, Easterners would probably have made the same discoveries and had their own industrial revolution, but geography made it much easier for Westerners - which meant that because people (in large groups) are all much the same, Westerners had their industrial revolution first. It was geography that took Looty to Balmoral rather than Albert to Beijing. (Morris, 2010, s. 565)

Både Diamond och Morris söker en över tid långt utsträckt logik bakom västvärldens ekonomiska och politiska dominans under 1900- och 2000-talen. Att söka svar på den frågan är de inte ensamma om. Ȧtskilliga forskare har ställt sig den frågan. Till skillnad från exempelvis André Gunder Frank (1998), Robert M. Marks (2004) och John Hobson (2007), vilka alla problematiserar utgångspunkterna för jämförelser mellan öst och väst genom att på olika sätt understryka ämnets komplexitet och peka på att frågan behandlas utifrån eurocentrerade utgångspunkter, strävar Diamond och Morris efter att finna mätbara orsakssamband, samt klargöra faktorer som gjorde processen nödvändig. Bägge representerar dessutom en inriktning där kultur- och socialhistoriska förhållanden väljs bort till förmån för naturvetenskapliga. Tonvikten på kvantifierbara data har kanske sin givna plats i en forskningstradition som intresserar sig för ekonomiska styrkeförhållanden, handelsflöden, samt modeller för ekonomisk tillväxt och befolkningsutveckling. Den har också visst stöd i ett växande intresse för miljöhistoriska frågor (Crosby, 1972; Crosby, 1986). Kvantitativa metoder är dock en sak, vad som mäts en annan. Inte något av de uppräknade sakområdena har utvecklats av sig själva utan har $\mathrm{i}$ alla tider och rum varit resultat av mänskliga handlingar. En undersökning av mänsklighetens historia kan mycket väl baseras på kvantitativa mätningar. Däremot finns anledning att resa principiella invändningar om de kvantitativa uppgifterna negligerar kulturella aspekter, däribland socialt och kulturellt arrangerade könsskillnader. Diamond och Morris har en antropologisk respektive arkeologisk inriktning, men inte heller i renodlat historiska analyser spelar de kulturella villkoren någon avgörande betydelse. I ett kort svar på frågan om varför den industriella revolutionen började i England menar de bägge historikerna John R. McNeill och William H. McNeill: 
[...] att vissa inhemska kännetecken (massor med kol och järn) och utvecklingsförlopp (den sociopolitiska miljön efter 1688) tillsammans med en förtätning av nätverket både i Storbritannien (vägar, kanaler, järnvägar och posttrafik) och i resten av världen (utlandshandel, kolonier och befolkningstillväxt) bidrog till att skapa de förhållanden som var nödvändiga för industrialiseringen, och där både friheten och motivationen till förnyelse fick ovanligt stora proportioner. (McNeill \& McNeill, 2006, s. 258)

Utan inbördes prioritet tycks således det mesta ha varit särskilt gynnsamt för Englands industrialisering. Världshistoriska översikter med syntetiska anspråk är dock ett särskilt fält som inte nödvändigtvis speglar pågående världshistorisk forskning. Men också i det sistnämnda tycks kultur- och könsaspekter ha varit svåra att etablera.

\section{Kön i världshistorien}

Trots att könsfrågor knappast utgör en del av världshistoriens huvudfåra vore det missvisande att säga att de helt saknas. I sin översikt diskuterar Patrick Manning tre inriktningar som enligt honom är urskiljbara. En strävar efter att synliggöra världshistoriens förbisedda kvinnor och beskriva deras respektive verksamhet. Resultatet är ett antal referensverk där historiskt betydelsefulla men i efterhand bortglömda kvinnor biograferas (Manning, 2003, s. 209; Adamson, 1998; Fischer, 1992; Vivante, 1999). Det är alltså en inriktning som erinrar om 1970-talets ambition att synliggöra kvinnors insatser i historien. Även om viktig kunskap därmed tillgängliggörs vore det en överdrift att hävda att referensverken har haft ett avgörande inflytande på världshistorisk forskning. En annan inriktning försöker att utifrån långa tidsperspektiv analysera de historiska rötterna till kvinnors och mäns skiftande könspositioner, där män i allmänhet varit överordnade kvinnor. Manning framhåller här historikern Gerda Lerners arbeten i vilka hon söker den patriarkala maktordningens rötter (Manning, 2003, s. 209; Lerner, 1986). Liknande perspektiv som Lerners aktualiserades på 1970-talet men återfinns också i moderna standardverk, som till exempel i den amerikanske historikern Peter N. Stearns världshistoria (Rubin, 1975/1996; Hartman, 1976; Stearns, 2000, s. 13-14). Inte heller den inriktningen kan dock sägas ha haft stor inverkan på världshistorisk forskning. Manning pekar emellertid också på en tredje, nämligen postkolonialt inspirerade studier där kvinnor $\mathrm{i}$ ett specifikt territorium är $\mathrm{i}$ fokus men där ansatsen - på grund av den koloniala eller postkoloniala kontexten - ändå är global. Det är framför allt inom detta fält, globalt i lokalt, eller glokalism som inriktningen också kallas, som Manning ser möjlighet till tätare utbyte mellan världshistoriska och könshistoriska perspektiv (Manning, 2003, s. 209). Manning hänvisar till flera arbeten som publicerats i början på 1990-talet som bekräftar en sådan möjlighet (Bush, 1990; Beckles, 1989; Devens, 1992). Utöver de tre inriktningar som Manning diskuterar kan också nämnas den socialhistoriska forskning som sedan några decennier tillbaka intresserar sig för demografiska förhållanden i olika delar av världen. I demografin, där giftermål, och därmed också kvinnor, män och barn är i fokus, är förstås bägge könen centrala socioekonomiska variabler (Hajnal, 1982; Pomeranz, 2000). Den amerikanske historikern Mary S. Hartman är dock i stort sett ensam om att även knyta det förflutnas varierande demografiska villkor till rådande maktrelationer mellan könen (Hartman, 2004).

Manning uppfattar således att en postkolonialt influerad könshistoria har möjlighet att göra könsliga avtryck i världshistorisk forskning. Här uppstår emellertid problem av teoretisk art som bland annat bottnar i förvirrande oklarheter i vad världshistoria egentligen är. Vad skiljer världshistoria från det numera använda uttrycket global historia? (Washbrook, 2013) Om komparationer mellan länder och institutioner utgör redskap i den globalhistoriska verktygslådan, är fokus på kontakter och flöden, ekonomiska som kulturella, ett annat 
(Pomeranz, 2000; Bayly, 2004). Dessa båda komponenter kan dock lika gärna räknas som världshistoria. En tredje infallsvinkel kan vara poststrukturalistiskt inspirerad. I den är målsättningen att söka underminera och destabilisera historieskrivningens stora berättelser. Det sistnämnda utgör en självklar aspekt i postkolonial kulturteori, som dock inte lika självklart kan definieras som vare sig världshistoria eller global historia. Edward Saids klassiska verk kan förstås räknas som både världs- och globalhistoria, vilket ytterligare understryker definitionssvårigheterna (Said, 1993). Försök att skilja det ena från det andra diskuteras bland historiker på flera håll, även i Sverige (Amirell, 2008, 2009; Müller \& Rydén, 2009; Torstendahl, 2009a, b). Frågan vad som ska räknas som transnationell, världshistoria eller globalhistoria är dock här av mindre intresse. Väsentligare är i stället de skiftande teoretiska perspektivens respektive förutsättningar och konsekvenser.

Utgångspunkt för postkolonial kulturteori är som sagt motståndet mot eurocentrerade metaberättelser om modernitetens framväxt, det vill säga västeuropeisk och amerikansk statsbildning, kapitalism och demokratisering (Schaub, 2013). Sådana metaberättelser utgör däremot grund för världshistoriska synteser av det slag som exempelvis Jared Diamond och Ian Morris producerar (ovan). Till de teoretiska implikationerna hör även $\mathrm{i}$ vilken utsträckning det är möjligt att homogenisera inbördes villkor i olika länder utan att ge en missvisande bild. Inte ens i länder som ekonomiskt och politiskt kan räknas som någorlunda enhetliga innebär könstillhörighet samma sak. Alla kvinnor i Sverige har inte samma könsliga erfarenheter, och många svenska kvinnor saknar de erfarenheter som kvinnor upplever i Tyskland, Irland eller USA. Motsvarande gäller förstås också för män. Däremot finns likheter i de nämnda ländernas könsmaktordning. Manning kommenterar inte dessa grundläggande meningsskiljaktigheter utan hans optimism baseras på att postkoloniala studier innefattar ämnen som sakligt sett berör områden som traditionellt är intressanta för världshistorisk forskning: migration, kommunikation, handel och andra kontakter.

Varför har då könsfrågor haft så svårt att etablera sig i det världshistoriska forskningsfältet? Här diskuteras främst tre skilda och samtidigt överlappande uppfattningar. Först kommer Patrick Mannings förklaring:

The well-established presumption that women's lives are acted out in the private sphere of the family rather than the public spheres of economy and politics has suggested that women's history is family history, and family history plays no great part in world history (Manning, 2003, s. 210).

Könsfrågor tolkas alltså som kvinnors historia, vilken i sin tur uppfattas som privata familjehistorier, och familjer spelar ingen stor roll i världshistorien. Det finns anledning att återkomma till Mannings slutsatser. Först kan emellertid konstateras att Mannings förklaring inte har fått stå oemotsagd. Den amerikanske historikern Merry Wiesner-Hanks menar att hon själv har gjort samma observation som Manning, nämligen att världshistorisk forskning tycks vara könsblind, men förklaringen, att kvinnors liv inte varit offentliga på samma sätt som mäns eller att kvinnor bara har varit delar av familjers privata historia, tillbakavisar hon bestämt. Hon avvisar också Mannings förklaring till könshistorikernas ointresse av världshistoria, att världshistorisk forskning ses som alltför inriktad på världssystemteorier (Wiesner-Hanks, 2007, s. 53-54). Vad beror då det ömsesidiga ointresset på? Efter en översiktlig genomgång av social-, kultur-, och könshistorisk forskning, där frånvaron av världshistoria bekräftas, konstaterar Wiesner-Hanks att trenden i könshistorisk forskning innefattar åtminstone två aspekter som kan bidra till att förklara de bristande anknytningarna mellan världshistoria och könshistoria. För det första präglas könshistorien av ambitionen att problematisera enkla orsakssamband, det vill säga de historiska 
villkorens komplikationer. Hur insiktsfulla de än kan vara ryms de inte i de världsomspännande synteser världshistorikerna producerar. För det andra, i könshistorisk forskning studeras huvudsakligen kvinnor och då för det mesta i forskarens eget land. Wiesner-Hanks exemplifierar med amerikansk forskning, men problemet att historisk forskning gör halt vid det egna landets gränser kan överföras till en nordisk kontext där uttrycket metodologisk nationalism făngar innebörden (Tvedt, 2012). En sådan territoriell begränsning, som för övrigt även gäller annan historisk forskning, är knappast förenlig med världshistoria. Att könshistorisk forskning har en tonvikt på kvinnor har historiska förklaringar - länge har kvinnor varit osynliga i historisk forskning - men medför också att den potential för studier av maktordningar i samhällen som kön, utnyttjad som en analytiskt strukturerande kategori, skulle kunna innebära, riskerar att gå förlorad (Scott, 1988).

Wiesner-Hanks menar således att den könshistoriska forskningens inriktning försvårar ömsesidigt utbyte. Precis som Manning är emellertid också Wiesner-Hanks optimistisk om framtida möjligheter. Även hon ser stor potential i den forskning som utifrån koloniala och postkoloniala teoribildningar studerar rörelser och kommunikation mellan länder och stater, alltså processer som oavsiktligt kom att ha världsavgörande betydelse. Sådana studier är världshistoria utan att ha ordet världshistoria i rubriken, och i de maktanalyserande utgångspunkterna finns dessutom inte sällan uttalade könsperspektiv (Wiesner-Hanks, 2007, s. 61). Även om Wiesner-Hanks i högre grad än Manning uppmärksammar begreppsliga olikheter och teoretiska motsättningar, anser hon uppenbarligen att de ändå är överkomliga. Kanske världshistoriens inriktning på strukturer och makroprocesser ändå går att förena med en mera kulturteoriorienterad poststrukturell ansats? Det är i alla fall den svenska historikern Anna Lindbergs avsikt då hon med utgångspunkt i Chandra Mohantys feministiska, poststrukturella och postkoloniala perspektiv visar att en fallstudie av könsrelationerna i Kerala i Sydindien faktiskt kan säga något om såväl lokala som globala processer. "Den förser oss med kunskap om 'det annorlunda', men också om de diskursiva och materiella regimer som opererar globalt." (Lindberg, 2004, s. 101)

Ett annat sätt än de postkoloniala att förhålla sig till dessa frågor framförs av den australiske historikern Marnie Hughes-Warrington, som i likhet med Wiesner-Hanks utgår från glappet mellan världshistoria och könshistoria: "Gender is commonly held to be a neglected topic in world history scholarship." (Hughes-Warrington 2011, s. 195) HughesWarrington menar dock att detta bara gäller könsrelationer $i$ världshistoria (gender in world history). Om man i stället vänder på frågan och studerar hur det förflutna varit påverkat $a v$ kön (gender of world history) finns i själva verket åtskilligt som talar för motsatsen; då är världshistoria också en könshistoria. Skillnaden mellan of och in kan verka hårfin eller till och med onödig, men efter en omfattande och katalogartad uppräkning av tankar om kön i världens många samhällen utifrån olika historiska studier och filosofiska utläggningar, från antik tid till nutid, menar Hughes-Warrington att kön och tankar om kön egentligen alltid har haft en helt avgörande betydelse i världshistorien.

There is no shortage of writing on gender in world history, even though the number of articles explicitly on that topic in the Journal of World History and the Journal of Global History is very low. What is still lacking, however, is widespread awareness of the extent that gender shapes world historical research, writing, and teaching, particularly works in which women are not mentioned. It is time for studies of gender in world history to be joined by those of the gender of world history writing. (HughesWarrington, 2011: s. 204) 
'Gender of world history' visar ett annat mönster än 'gender in world history'. Det råder således faktiskt ingen brist på könsperspektiv i världens historia. Det som fattas är ett medvetande om detta faktum, så att kön kan integreras i både undervisning och forskning om världens historia. Hughes-Warringtons distinktion innebär dock inte att tidigare framförd kritik mot den världshistoriska forskningens könsblindhet saknar fog. Kritikerna förnekar ju inte könsrelationernas betydelse i det förflutna utan hävdar snarast frånvaron av precis det medvetande som Hughes-Warrington efterlyser. Hur ett sådant medvetande ska kommuniceras och även implementeras ger Hughes-Warrington inga närmare besked om. Det är således alltjämt en öppen fråga.

Sammanfattningsvis, den kritik som riktas mot världshistorisk forskning för dess förbiseende av könsfrågor kan alltså summeras på ett sätt som också delvis förklarar världshistorikernas bristande intresse: att kvinnors historiska betydelse mest har betraktats som privat, i familjen (Manning), att könshistorikerna antingen är för nationalstatligt bundna eller komplicerar historiska processer så att dessa omöjligt kan ingå i världshistorikernas synteser (Wiesner-Hanks), att världshistorisk forskning saknar medvetande om betydelsen av kön i världens historia (Hughes-Warrington). Mannings kartläggning av världshistorisk forskning är från början på 2000-talet, medan WiesnerHanks och Hughes Warrington diskuterar frågan några år senare och då på basis utifrån huvudsakligen könshistorisk forskning. I det ena fallet studeras i huvudsak hur sådan forskning har tagit sig an världshistoriska frågor, i det andra hur världshistoriskt betydelsefulla intellektuella uppfattat könsskillnaders betydelse. Frågan är vad som sägs i världshistorisk forskning om dessa aspekter? Har något hänt efter den tidpunkt, alltså 2003, då Manning avslutar sin inventering? Har Hughes Warrington rätt i - utan att själv undersöka saken - att exempelvis Journal of World History endast har ett litet antal artiklar på detta tema?

\section{Journal of World History}

Journal of World History grundades år 1990 av historikern Jerry H. Bentley (1945-2012), som ägnade en stor del av sitt forskarliv åt världshistoriska frågor. Tidskriften publicerar forskning som intresserar sig för globala processer och transkulturella perspektiv, och redan av tidskriftens namn framgår att det är världshistoria man intresserar sig för. Etableringsåret 1990 överensstämmer för övrigt med den ovan omnämnde Patrick Mannings uppfattning om att det var först då som världshistoria blev etablerat som ett forskningsfält. Tidigare sågs nämligen världshistoria huvudsakligen som något man undervisade $i$, men inte forskade om (Manning, 2003, s. 77-78). Frågan är då vad för slags forskning som redovisas i Journal of World History de senaste åren och i vilken grad könsaspekter diskuteras.

En genomgång av tidskriftens utgivning från och med 2001 ger en intressant inblick i världshistoriens forskningstraditioner och hur dessa har förändrats. Först och främst kan konstateras att antalet årligt publicerade artiklar har blivit flera med tiden; år 2001 publicerades elva och år 2013 var man uppe i nitton, (inklusive de korta introduktionerna till tidskriftens olika specialnummer). År 2001 utkom tidskriften med två nummer per år medan man från och med år 2003 utkommer med fyra. Det tilltagande antalet artiklar speglar rimligtvis att världshistoria är ett växande forskningsfält som engagerar allt fler. Ett genomsnitt för de undersökta åren är 15 artiklar per år och de undersökta åren omfattar beståndet knappt 200. Några teman är återkommande och kan nog betraktas som givna i en världshistorisk forskningstradition. Olika typer av gränsöverskridande rörelser som spridningsförlopp för sjukdomar (Catanach, 2001; Webb, 2005), idéströmningar, klimatförändringar (Atwell 2001; Cao, Li \& Yang 2012), migration (Northrup, 2003), resor 
(Bagchi, 2003) och vetenskapliga utbyten (Grimmer-Solem, 2005) återfinns exempelvis i flera av tidskriftens nummer. Under rubriken Forum (2013) samlas fyra bidrag som alla diskuterar olika aspekter på hälsa och sjukdom. I ett nummer (2010) behandlas kosmopolitanism i sex olika artiklar. Krig och erövringar är också ständigt återkommande ämnen (Manz, 2002; Speidel, 2002) och i det första numret 2014 behandlar inte mindre än fyra bidrag den militära revolutionen. En särställning intar ämnen som imperier och imperialism, handel och mission. Artiklar som utifrån varierande aspekter behandlar dessa teman finns i nästan varje nummer av tidskriften. Imperiebildningarna i Kina, Indien och i östra Medelhavsområdet tycks då vara särskilt populära. I varje årgång tar åtminstone någon artikel upp de imperier som i olika perioder har funnits där, och som på skiftande sätt har påverkat världens villkor.

Även om genomgången här endast gäller drygt tio år märks både förändring och kontinuitet. Intresset är fortsatt stort för imperiers historia och ekonomiska dominansförhållanden. Samtidigt förändras teoretiska och metodologiska utgångspunkter på ett sätt som ligger i linje med generella strömningar i historisk forskning, även sådan som rör ekonomiska villkor, där kulturella aspekter framhävs (McCloskey, 2010). Exempelvis finns flera artiklar som intresserar sig för språk, diskurs, dekonstruktion och retorik (Duara, 2001; Ng, 2003; Drake, 2004). Det saknas således inte kulturorienterade teman. De kulturteoretiska ramverken varierar men i flera bidrag riktas kritik mot eurocentrerade perspektiv och mot västvärldens metaberättelser om sin väg mot modernitet, (alltså synsätt som i vid mening kan hänföras till postkolonial kulturteori), utan att ordet postkolonial finns i artikelrubriken (Keita, 2005; Prestholdt, 2007; O'Brien, 2012). Världshistoriskt kanske självklara ämnen som handel och handelsflöden behandlas utifrån skiftande kulturteoretiska utgångspunkter. I exempelvis specialnumret om kinesiskt porslin och porslinshandeln tar både introduktion och temanumrets artiklar sin utgångspunkt i perspektiv som på sistone formerat området materiell kultur (McDowall \& Gerritsen, 2012).

Artiklarna i Journal of World History faller alltså delvis in i historieforskningens generella trender, där kulturteoretiska aspekter framhävs. I hög grad redovisar tidskriftens olika bidrag inträngande och mångfasetterad forskning rörande åtskilliga geografiska rum. Innehållsligt speglar tidskriften väl sina globala och transnationella ambitioner. Tidskriften har förstås också egna specialiteter. En utgörs av en omfattande recensionsavdelning. Ett stort antal nyutgivna böcker recenseras i varje nummer och av titlarna att döma innehåller flera böcker också könsperspektiv. En annan specialitet är att i hög grad publicera historiografiska artiklar. I stort sett i varje årgång återfinns något historiografiskt bidrag, inte sällan kritiskt mot tidigare traditioner. Exempelvis diskuteras begreppet civilisation på basis av äldre uppfattningar om världens historia (Duara, 2004). Världshistoriens kontext tas upp i flera tidskriftsbidrag utifrån skiftande och för ämnet självkritiska utgångspunkter (Christian, 2003; Sutherland, 2007; Sachsenmaier, 2007). Världshistoriens distanserade relation till socialhistoria diskuteras också (Stearns, 2007; Pomeranz, 2007). Som helhet speglar således tidskriftens artiklar ett forskningsfält med plats för både självreflexion och öppenhet. En tredje och i det här sammanhanget särskilt relevant specialitet för tidskriften är att, bortsett från Wiesner-Hanks ovan omnämnda artikel samt ett antal bokrecensioner, finns inte en enda artikel med ordet gender i rubriken. Med tanke på att influenser från en rad andra kulturella fält ändå har sugits upp i tidskriftens artiklar förhåller man sig således anmärkningsvärt reserverad till befintlig könshistorisk forskning. Det verkar således som om Hughes Warrington har dragit en alltför försiktig slutsats då hon menar att antalet artiklar på detta tema var litet (ovan); i själva verket fanns inga. Vid en närmare granskning kan emellertid intrycket modifieras något. I ett mindre antal artiklar ger nämligen ämnesvalet anledning att tro att innehållet har med könsfrågor att göra. Sammanlagt sex artiklar av nästan 200 behöver studeras närmare för att nå säkra besked. 
Två artiklar visar på olika sätt att internationell politik inte kan betraktas som något könsneutralt. I den amerikanska historikern Judith P. Zinssers analys av FN:s arbete för kvinnorättsfrågor är maktrelationerna mellan könen centrala. I artikeln behandlas såväl de regeringsarrangerade konferenserna i Mexiko City, Köpenhamn och Nairobi som ett stort antal NGO-organiserade tribuner och forum. Trots att besluts- och strategidokumenten präglades av kalla krigets ideologiska meningsskiljaktigheter och den tydliga motsättningen mellan rika och fattiga länder menar Zinsser att konferenserna har varit till gagn för kvinnors likarättsarbete, inte bara internationellt utan också i de egna länderna (Zinsser, 2002, s. 141-142). Zinsser framhåller även hur språket i dokumenten förändrades. I Mexiko City 1975 präglades det av patriarkala traditioner där kvinnor definierades som offer för krafter utanför deras kontroll, eller som marginaliserade i den modell av världen som dokumenten implicit byggde på. I Nairobi tio år senare var språkbruket ett annat. Borta var enkla essentialistiska kategoriseringar, i stället hade kvinnor formerats till aktiva agenter $\mathrm{i}$ ansträngningarna för att forma nya internationella institutioner och praktiker (Zinsser, 2002, s. 143-144). I den amerikanska historikern Karen Garners artikel om World Young Women's Christian Association (World YWCA) och organisationens förhållande till Japan i andra världskrigets slutskede tas ett liknande grepp på internationell politik. World YWCA var en kanske numera bortglömd del av det tidiga 1900-talets internationalistiska strävanden som senare utgjorde grund för FN. Organisationen samlade kristna kvinnor över hela världen i syfte att stärka deras politiska engagemang. Kriget medförde dock stora svårigheter att bevara enighet i organisationen. Nationalistiska strömningar tog över. Efter Japans ockupation av Manchuriet hade särskilt de kinesiska kvinnorna svårt att fördra sina japanska systrar som de betraktade som alltför undfallande gentemot Japans imperialistiska politik. De japanska kvinnorna ansågs behöva särskild skolning och först i samband med föreningens möte i Japan 1947 togs de till nåder igen - då på ett program dikterat av amerikanska villkor. World YWCA och händelserna i Japan kan tyckas vara en historisk randanmärkning men Garner hävdar:

[...] all have something to learn from this historic episode because the World YWCA visitation to occupied Japan in 1947 exposed a gendered and racialized power structure in Japan and, by extension, in the U.S.-dominated international arena, that echoes in the current discourse about "women and democracy". (Garner, 2004, s. 191)

De bägge artiklarnas studieobjekt är förvisso kvinnors internationella politiska arbete, men avsikten är att blottlägga generella och överstatliga könspolitiska maktstrukturer. I ytterligare tre artiklar är kvinnor i fokus, men endast en knyter uttryckligen an till könsliga maktstrukturer. I alla tre behandlas teman som har med mytbildning och fiktion att göra, alltså kulturella aspekter på det förflutna. Den amerikanska historikern Christine IsomVerhaaren visar hur kvinnor har utnyttjats för politiska syften, från 1500-talet fram till 2000-talet och hon pekar då på deras olika symboliska funktioner. På 1500-talet symboliserade franska kvinnor i det osmanska imperiets harem en politisk och militär allians mellan en kristen kung och en muslimsk sultan, medan nutidens berättelser om kvinnor utgör svepskäl för västlig dominans i Mellanöstern (Isom-Verhaaren, 2006). För IsomVerhaaren är dock inte könsanalysen den centrala trots att hon i praktiken ändå gör en sådan. Hon hänvisar i stället allmänt till symbolanvändningens stormaktspolitiska implikationer. Motsvarande kan sägas om den amerikanska historikern Taymiya R. Zamans artikel om den portugisiska kvinnan Juliana Dias da Costa, vilken under 1700-talet hade stort inflytande vid hovet hos den moguliska kungen Bahadur Shah I. Fantasifulla historier om henne cirkulerade ända fram till det brittiska styrets kollaps 1947 och i artikeln formas 
Juliana Dias da Costas liv till en livsberättelse som inte bara rör henne själv utan även jesuitmissionens uppgång och fall i Indien (Zaman, 2012).

I den kanadensiske historikern Adrian Schuberts artikel är däremot den könsliga maktordningen en utgångspunkt. Schubert tar avstamp i hjältekulter i Europa, där flertalet nationalhjältar är män och för det mesta har utfört sina bragder i krig, som dock också kunde rymma andra genusordningar än traditionella. I sin artikel vill Schubert överbrygga de eurocentrerade perspektiven genom att analysera kvinnliga krigshjältar och jämföra dem sinsemellan, en i Europa och två i Indien: vad skiljer och vad förenar? På olika sätt har de tre kvinnliga krigshjältarna blivit delar av sina respektive länders minnesproduktion, i dikter, målningar, musik och andra kulturyttringar. Varken i Spanien eller i Indien var det emellertid oproblematiskt att en kvinna var krigshjälte, men i Indien fanns religiösa traditioner (kvinnliga krigsgudinnor) som ändå öppnade för möjligheten. Där var det snarast det faktum att de bägge krigshjältarna var änkor som var svårast att hantera. Alla tre utmanade således rådande genusnormer och alla tre fyllde olika politiska syften i de bägge ländernas nationella medvetande. Trots skillnader mellan de bägge ländernas minneskulturer kan Schubert konstatera att likheterna var överväldigande, vilket visar att europeiska perspektiv har mycket att vinna på komparation med utomeuropeiska förhållanden (Schubert, 2012).

Sammanfattningsvis är det tydligt att artiklarna ovan speglar hur världshistorisk forskning på olika sätt har tagit intryck av kulturella perspektiv. Utöver den redan omnämnda artikeln av Wiesner-Hanks drivs dock uttalat könshistoriska infallsvinklar endast i tre, totalt blir det således fyra. Ytterligare en tillkommer och det är den sista i den här artikelns fördjupade genomgång. Delvis utgör den en fortsättning på den diskussion Merry Wiesner-Hanks initierat och avsikten är egentligen densamma som föreligger här, nämligen att försöka visa hur världshistorisk forskning kan göra analytiska vinster genom att utnyttja könsperspektiv i sina studier. I fokus för de bägge amerikanska historikerna Ulrike Strasser och Heidi Tinsman är dock inte kvinnor utan i stället män och maskulinitet. I likhet med Merry Wiesner-Hanks noterar även Strasser och Tinsman att skilda grundförutsättningar motverkar ett större utbyte mellan världshistorisk och könshistorisk forskning. Enligt dem går den stora skiljelinjen mellan materialistiska och kulturella perspektiv: "[...] it is a heavily materialist world history that faces off with a predominantly culturalist history of gender and sexuality." (Strasser \& Tinsman, 2010, s. 77) Strasser och Tinsman menar att varken kulturteori eller könsperspektiv har gjort några betydelsefulla avtryck i världshistorisk forskning. De konstaterar därför:

More frustrating still, while a materialist emphasis does not per se preclude gender analysis - one only needs to recall the many superb feminist labor histories written within national frameworks - much of world history marches along merrily without paying much attention to gender and sexuality at all (Strasser \& Tinsman, 2010, s. 80).

Om hänsyn tas till artiklarna som publicerats i Journal of World History de senaste tretton åren är det emellertid tydligt att det inte är kulturteori som världshistorisk forskning ryggar inför. I stället tycks det vara könsliga aspekter som avskräcker, vilket även bekräftas då Strasser och Tinsman konstaterar att många världshistoriskt intressanta feministiska studier om arbete lämnas åt sidan, trots att teoribildningen i dem är materialistisk. Strasser och Tinsman vill dock föreslå lösningar för konstruktiv samverkan och tar då sin utgångspunkt $i$ latinamerikansk forskning. Det är nämligen ett fält "[...] that often has fluidly blended culturalist and materialist traditions and focused on masculinity in ways that are highly relevant to debates within world history today" (Strasser \& Tinsman, 2010, s. 78). De 
menar att latinamerikansk historieskrivning har stora likheter med världshistorisk. I bägge fallen rör de dominerande narrativen imperiebyggande, global kapitalism och statsformering, och de tongivande perspektiven har i båda varit materialistiskt fotade. Men till skillnad frăn världshistorisk forskning har köns- och sexualitetsstudier varit integrerade i latinamerikaforskningen sedan åtminstone 25 år tillbaka och bland annat varit särskilt betydelsefulla i motarbetandet av essentialiska tolkningar av Latinamerikas efterblivenhet (Strasser \& Tinsman, 2010, s. 84).

Strasser och Tinsman lyfter fram några inriktningar i de latinamerikanska maskulinitetsstudierna som i särskilt hög grad borde kunna inspirera världshistorisk forskning, inte minst för att den ofta rör ämnen där man tror sig veta att inga kvinnor fanns och därför bara intresserar sig för män, men då endast som könsneutrala individer. Även om denna uppfattning sannolikt är felaktig - kvinnor har i allmänhet funnits där män har varit och vice versa - understryker Strasser och Tinsman att också män är könsliga varelser och sett $\mathrm{i}$ sådant ljus har maskulinitetsstudier kunnat fördjupa förklaringar till exempelvis de imperier som tog form i Latinamerika långt före spanjorers och portugisers erövringar. Den långlivade manlighetskultur, där sexuellt våld och manlig heder utgjorde en väsentlig grund $i$ en redan given maktstruktur, har setts som en avgörande faktor för imperiernas uppbyggnad och överlevnad. Men den har också utgjort fundament i de maktordningar spanjorer och portugiser byggde upp. Vidare, i forskning om kontinentens modernisering har maskulinitet varit avgörande för förståelsen av processens historiska utformning. Relationen mellan manligt normerad nationsbildning och en familjebildning, där män överordnats kvinnor, har varit tydlig och enligt Strasser och Tinsman har de latinamerikanska förhållandena flera paralleller i världshistorien (Strasser \& Tinsman, 2010, s. 91-96).

Kort sagt, Strasser och Tinsman visar alltså hur flera olika forskningsinriktningar, som intresserar sig för makro-processer i världshistorien, skulle kunna vinna i förklaringsvärde om de beaktar att objektet för studierna också ingår i ett könsligt arrangerat maktsystem. I deras fall illustreras det av hur maskulinitet och manlig makt konstituerades på olika men delvis överlappande sätt i de politiska projekt som resulterade i Inkaväldet, europeisk statsbildning och spansk kolonialism (Strasser \& Tinsman, 2010, s. 94-95). Över huvudtaget efterlyser de en sorts mänsklighet i de imperier, strukturer, globala processer och transnationella jämförelser som världshistorisk forskning ser som sina huvudobjekt (Strasser \& Tinsman, 2010, s. 96). I all enkelhet innebär det grund för att formulera en hypotetisk uppfattning: att det faktiskt inte finns några könsneutrala historiska processer, ens på makro-nivå. Den aspekten ska nu belysas i en diskussion om familj som en del av världshistorien.

\section{Familjehistoria som världshistoria: imperier och krig som exempel}

Patrick Mannings förklaring till den världshistoriska forskningens ointresse av könsperspektiv är som sagts ovan att könshistoria uppfattas som kvinnohistoria och att kvinnors historia mestadels har framlevts utanför offentligheten, i det privata familjelivet (Manning, 2003, s. 210). Manning har naturligtvis rätt. Merparten av könshistorisk forskning har kvinnor som studieobjekt. I lägre grad än män har kvinnor i historien haft offentliga och formellt maktutövande positioner. Mannings förklaring är emellertid samtidigt missvisande. Åtskilliga kvinnors historia har förvisso utspelats inom familjelivets ramar, men detsamma kan också sägas om flertalet män. Av flera skäl, som strax framgår, kan det till och med hävdas att familjens historia faktiskt är världshistoria, även om det inte märks i världshistorisk forskning. I det följande exemplifieras det utifrån några enkla iakttagelser om imperier och krig. 
Imperier hör till världshistoriens mest gångbara teman. I en på svenska utgiven världshistorisk översikt understryker den norske historikern Tore Linné Eriksen att vår tids stater är nya fenomen. Länge var det i stället vanligast att människor bodde i lösligt sammanhållna imperier eller i samhällen som saknade fastlagda gränser. Eriksen menar att det nya med att bo i länder, där territoriella gränser tydligt exkluderar och inkluderar, kan vara skäl till att imperier och imperialism utgör ett fortsatt populärt tema i vår tids globalhistoriska forskning (Eriksen, 2014). Enligt honom granskas imperierna numera utifrån nya aspekter, bland annat könsperspektiv, och på så vis är imperiehistorien ständigt levande (Eriksen, 2014, s. 661). I genomgången av artiklarna i Journal of World History noterades följaktligen att åtskilliga bidrag gäller just imperier men också att inte något av dem behandlar imperiernas könsliga maktstrukturer. Utifrån det enkla antagandet att imperier varken växer eller går under på egen hand är det emellertid ingen omöjlig tankeoperation att betrakta imperier utifrån ett könsperspektiv. Det kan ske på olika sätt. I det här fallet väljs att visa familjens betydelse.

Imperiers politiska regentskap är tydliga exempel på manligt könade maktstrukturer som formas utifrån bland annat familj och släkt. Oavsett om den högste regenten titulerades kung, furste, kejsare, kalif eller sultan innehades titeln oftast, men inte alltid, av män. Regentskapet motiverades av bestämda släktlinjer och på så vis formerades härskarätter till politiska dynastier som även lagt grund för historieskrivningens epoker. Tydligast är kanske mönstret i faraonernas Egypten, kejsarnas Kina och shahernas Iran, men även i andra delar av världen, som till exempel i 1600-talets England och Sverige, eller i Kanem-Bornu (ca 1000-1897), präglades det politiska styret av ett dynastiskt tänkande kring regentskap. Det byggdes in i tidens härskarideologi. De dynastiska principerna prioriterade överallt män. Kvinnliga regenter under 1600 - och 1700-talen var i allmänhet nödlösningar i situationer där inga män med närmre släktskap till föregångaren fanns att tillgå. I valet mellan syster och bror vann ofta brodern, och om de kvinnliga härskarna gifte sig övergick regentskapet till deras makar. Givetvis finns undantag från denna regel. Katarina den stora (1729-1796) blev till exempel regerande rysk tsarinna efter att ha genomfört en palatskupp mot sin make. Hennes regeringstid var en dryg sextioårsperiod under de århundraden då de ryska tsarerna räknades som tillhöriga dynastin Romanov (1613-1917). I likhet med andra långlivade dynastier bestod regenterna $\mathrm{i}$ ätten Romanov dock inte uteslutande av manliga ätteläggar i biologiskt rakt nedstigande led från anfadern Michail Romanov. Tronföljarval och giftermålsförbindelser medförde att blodsbanden till anfadern med tiden blev alltmera uttunnade. Släktlinjerna fortsatte emellertid att formas i namnet Romanov (Sjöberg, 2014, s. 523-524).

Släkt och familj är nära samhöriga men är ändå inte samma sak, och bägge begreppen innefattar dessutom historiskt föränderliga förhållanden. Vad som räknas till det ena eller andra varierar, men oavsett konstellation, polygama eller monogama förbindelser, spelar kön och sexualitet en avgörande roll. Kvinnor i regenters harem, eunucker i kejserliga hov och palats understryker det liksom de officiellt ingångna föreningar mellan kvinnor och män som har format politiskt mäktiga dynastier.

Signifikativt för 1600- och 1700-talen var det politiska familjelivets offentlighet (Burke, 1994). Kungar, kejsare, sultaner, drottningar och andra furstepersoner höll sig med harem, hov, hustrur och älskare. Kvinnors generella juridiska underordning visavi män fyllde strukturellt syftet att säkra det politiska maktinnehavet i händerna på män. Men det skedde på olika sätt. I polygama furstehus motverkade ett stort antal furstliga avkommor konkurrens från rivaliserande släktgrupper och i monogama var det just monogamin som idealt sett skulle förhindra samma sak. 
Oavsett monogama eller polygama villkor kunde umgänget vid hovet vara både vidlyftigt och samtidigt avgörande för det politiska styret. I den amerikanska historikern Joan B. Landes studie av revolutionstidens Frankrike framgår hur maktskapande enväldets hovliv kunde vara - även för kvinnor - och det finns ingen anledning att tro att det skulle vara dramatiskt annorlunda i andra hovkulturer (Landes, 1988). Vid hoven vistades även kvinnor och män som inte var släkt med regenten. För dem var inhämtande av utbildning, erfarenheter, kontakter och umgänge de huvudsakliga sysselsättningarna. Regenternas familjeliv utspelades således med hovlivet som fond - och för maktaspirerande adelsfamiljer som skickade sina söner och döttrar till regenternas hov utgjorde denna arena dessutom en viktig äktenskapsmarknad (Persson, 2014).

Släkt och familj var således en väsentlig aspekt av tidigmodern politisk maktstruktur. Iakttagelsen gäller för såväl Vasadynastin i det perifera Sverige som det samtida och i världshistorisk forskning mer betydande Kina under Mingdynastin. Det är således fråga om ett generellt drag som med varierande betydelser etablerades överallt där regentskap knöts till släktskapsbaserade dynastier. Giftermålet år 1479 mellan de bägge kusinerna Isabella I av Kastilien och Ferdinand II av Aragonien visar hur föreningen mellan makar också knöt samman territorier. Att det så småningom enade kungariket Spanien under Karl $\mathrm{V}$ kom att bli en del av det vidsträckta och lösligt sammanhållna tysk-romerska riket och knytas till dynastin Habsburg, var även det ett resultat av giftermålspolitik (Sennefelt, 2014, s. 555). I Sverige, som aldrig har varit ett imperium men likväl en territoriell stormakt i 1600-talets Europa (fram till freden i Nystad 1721), försökte Vasa-regenterna, liksom övriga kungahus i Europa, att iscensätta utrikespolitiskt strategiska giftermål. Huruvida giftermålspolitiken var framgångsrik kan diskuteras, särskilt som två av Vasa-dynastins regenter, drottning Kristina (regerade 1644-1654) och Karl XII (regerade 1697-1718) inte gifte sig alls. Likväl eftersträvade Vasa-regenterna giftermål i enlighet med tidens maktpolitiska mönster och de släktrelationer som därigenom skapades blev samtidigt viktiga politiska relationer. Det dynastiska tänkandet kring politiskt regentskap innebar särskilda politiska överväganden, $\mathrm{i}$ synnerhet om det var aktuellt att etablera en ny dynasti på tronen. Risken för ett totalt brott i Vasa-dynastins kontinuitet i samband med drottningen Ulrika Eleonoras nedläggelse av tronen 1720 till förmån för sin make, Fredrik I av Hessen, motverkades av exempelvis både ny regeringsform och särskilda försäkringar om framtida succession. Till skillnad mot tidigare blev tronföljden då uteslutande manlig. I ett senare fall, då det saknades biologiska släktband mellan företrädare och efterträdare på tronen, var i stället adoption en fiffig lösning för en bibehållen dynastisk kontinuitet, trots att det reella släktskapet blev ett annat. Så importerades exempelvis dynastin Bernadotte till politiskt regentskap i Sverige i början på 1800-talet (Alm \& Ekedahl, 2004).

Släkt och familj, där maktstrukturerna speglade en 'det enda könets värld', var alltså inte bara grund för politiskt regentskap utan giftermålen var också ett mer eller mindre framgångsrikt recept för att utvidga riksbildningar. Anmärkningsvärt är därför att denna strukturella familjeaspekt inte spelar en mera framskjuten roll i världshistorisk imperieforskning.

De flesta av historiens många människor verkade dock inte som regenter och var inte delaktiga i politiskt mäktiga dynastier. I både bevarat källmaterial och i världshistorisk forskning har de därför gjort få eller inga avtryck. Likväl finns belägg för att den könade maktordning som var aktuell i det politiska regentskapet också hade motsvarighet bland socialt lägre skikt. Hushållsorganisationen, där mannen som husbonde var överordnad hustru, barn och andra hushållsmedlemmar, var ett normativt familjeideal, från hög till låg. Ett med det förra sammanhängande exempel är tidigmodern krigföring. I de krig som gisslade Europa under 1600-talet flyttade nämligen familjeliv och hushåll med ut $\mathrm{i}$ fält. 
Officerarna medförde sina familjer och höll sig med tjänstefolk i varierande omfattning. Även för gemena soldater var det viktigt att ordna tillvaron i fält hushållsvis. Långvariga krig byggde på att soldaterna själva skaffade sig försörjning. Hantverksproduktion, handel och plundring gav nödvändiga utkomster, men krävde att soldaterna hade medhjälpare. Inte sällan var det hustrur och barn som bistod. I en undersökning av de svenska fälttågen i Polen, Ukraina och Tyskland, under främst 1600-talet och 1700-talets inledande år, framgår att en militär manligt homosocial organisation i fält var integrerad med en hushållsorganisation där kvinnor och barn rymdes (Sjöberg, 2011). Homosocialitet, den manliga maktstrukturen, förutsatte alltså en hushållsorganisation, där kvinnor assisterade sina makar - och vice versa. De svenska krigsartiklarna, inspirerade av tyska och nederländska förlagor, tillät således soldaterna att medföra hustrur i fält. Förutsättningen var dock legitimt ingångna giftermål. Militärledningen såg $\mathrm{i}$ dem ett medel för att upprätthålla sedlighet bland soldaterna och stävja social oro. Men familjeliv i fält tryggade också i någon mån försörjningen av manskap. Familjer var idealt sett en garanti för att soldaterna hellre skulle stanna kvar än att fly, eller söka tjänst i någon annan armé. Av olika skäl övergavs hushållssystemet i fält successivt under 1800-talets lopp. För svensk del hade fälttåg utomlands då förlorat sin aktualitet men viktigare var att soldaternas hustrur och barn fick en tryggad försörjning i hemlandet. Familj och hushåll hade således ett avgörande inflytande på krigsorganisationerna också då de upphörde att vara delar av en fältmässig organisation (Sjöberg, 2008).

Den svenska krigsmaktens erövringar låg till grund för Sveriges kortvariga stormaktstid. Villkoren i den svenska militära organisationen var dock inte unika utan hade samtida utländska motsvarigheter (Lynn II, 2008). Hushåll och familj i fält, kombinerad med den militära apparatens hierarkiskt ordnade homosociala organisationen, var således typiskt för den tidigmoderna epokens krig, oavsett om krigen ledde till utvidgade riksbildningar eller territoriella förluster. Kombinationen av hushåll och homosocialitet var dessutom inget nytt påfund, utan en tidigare prövad modell. Äldre förlagor finns. Antikens skriftställare nämner företeelsen. Germanicus hade med sig både hustru och de fem barnen i fält och Dio Cassius (56.20) skriver om slaget vid Teuterburgerskogen år 9 e. Kr. att de romerska soldaterna hade med sig kvinnor, barn och slavar. Fiendestyrkorna var inte annorlunda. Romarna visade nämligen upp tillfångatagna kvinnor och barn i triumftågen (Östenberg, 2009, s. 135-144).

I krig var genusordningarna både traditionella och uppochnedvända. Till de traditionella räknas att det var män som ordnades hierarkiskt som militärer, medan kvinnors medverkan inte krävde annat än en legitim relation till en av militärens män. Som exempel på de uppochnedvända kan anföras kvinnor som plundrade och män som bakade bröd. I krigsretoriken var könskonfigurationerna emellertid stereotypt traditionella; kvinnor och barn framställdes som familj och kommunicerades som ett slags oskyldighetens markörer (Sjöberg, 2008).

Familjelivets könsliga villkor vittnar således om väsentliga aspekter av krigens och erövringarnas historia. Men det är inte utifrån dessa infallsvinklar världshistorisk forskning analyserar krig. I stället behandlas militära strategier och teknologier som om dessa vore i avsaknad av mänskliga - och därmed könade - krafter (Romaniello, 2014; Eaton \& Wagoner, 2014; Andrade, Kang \& Cooper, 2014; Ágoston, 2014). Motsvarande kan sägas om den forskning som behandlar imperiers uppgång och fall - trots att imperierna lika tydligt har en motsvarande familjehistoria. 


\section{Avslutning}

Varför världshistorisk forskning inte intresserar sig för det förflutnas könsliga villkor har inget självklart svar. Skälet är i varje fall inte att denna forskningsinriktning skulle vara generell motståndare till kulturteoretiska perspektiv. Orsaken kan heller inte vara att det förflutna skulle vara mindre avhängigt könsliga villkor än dagens samhällen. Kanske är det mindre meningsfullt att spekulera om orsakerna bakom forskningsinriktningens könsblindhet och i stället koncentrera sig på att försöka visa vilket förklaringsvärde ett könsperspektiv kan ha. De amerikanska historikerna Strasser och Tinsman visar hur analyser av Latinamerikas imperier dragit nytta av forskningen om maskulinitet och att detta skulle kunna utnyttjas $i$ annan världshistorisk forskning. Här behandlas hur imperier och stormakter generellt utformat politiskt regentskap utifrån manligt dominerade familjeoch släktband. Både kvinnor och män har framlevt sina liv i familjer, vilket bekräftas av den demografiska forskningen. Men familjelivet har inte alltid varit en privat historia. I den här artikeln hävdas att familjeliv till och med kan ses som världspolitik. Därmed understryks att det inte är familjelivet som har gjort kvinnor osynliga och män synliga i världshistorisk forskning. 


\section{Referenser}

Adamson, L. G. (1998). Notable Women in World History: A Guide to Recommended Biographies and Autobiographies. Westport, CT: Greenwood Press.

Ágoston, G. (2014). Firearms and Military Adaption: The Ottomans and the European Military Revolution, 1450-1800. Journal of World History, 25(1). http://dx.doi.org/10.1353/jwh.2014.0005

Alm, M. \& Ekedahl N. (2004). En dynasti blir till: medier, myter och makt kring Karl XIV J ohan. Historisk tidskrift, 3.

Amirell, S. E. (2008). Den världshistoriska vändningen. Möjligheter och problem i relation till svensk historisk forskning. Historisk tidskrift, 4.

Amirell, S. E. (2009). Den världshistoriska vändningen och strävan att övervinna det nationella paradigmet. Ett svar till Rolf Torstendahl. Historisk tidskrift, 2.

Andrade, T., Kang, H. H. \& Cooper, K. (2014). A Korean Military Revolution?: Parallel Military Innovations in East Asia and Europe. Journal of World History, 25(1). http://dx.doi.org/10.1353/jwh.2014.0000

Atwell, W. S. (2001). Volcanism and Short-Term Climatic Change in East Asian and World History, c. 1200-1699. Journal of World History, 12(1).

http://dx.doi.org/10.1353/jwh.2001.0002

Bagchi, K. (2003). An Orientalist in the Orient: Richard Garbe's Indian Journey, 1885-1886. Journal of World History, 14(3).

http://dx.doi.org/10.1353/jwh.2003.0030

Bayly, C. (2004). The Birth of the Modern World, 1780-1914: Global connections and comparisons. Oxford: Blackwell.

Burke, P. (1994). The Fabrication of Louis XIV, Yale: Yale University Press.

Bush, B. (1990). Slave Women in Caribbean Society, 1650-1838. Bloomington: Indiana University Press.

Beckles, H. McD. (1989). Natural Rebels: A Social History of Enslaved Black Women in Barbados. London: Zed Books.

Catanach, I. J. (2001). The 'Globalization' of Disease? India and the Plague. Journal of World History, 12(1). http://dx.doi.org/10.1353/jwh.2001.0005

Cao S., Li, Y. \& Yang, B. (2012). Mt. Tambora, Climatic Changes, and China's Decline in the Nineteenth Century. Journal of World History, 23(3).

http://dx.doi.org/10.1353/jwh.2012.0066

Christian, D. (2003). World History in Context. Journal of World History, 14(4). http://dx.doi.org/10.1353/jwh.2003.0048

Crosby, A. W. (1972). The Columbian Exchange: Biological and Cultural Consequences of 1492. Westport: Greenwood Press.

Crosby, A. W. (1986). Ecological Imperialism: The Biological Expansion of Europe, 9001900. Cambridge: Cambridge University Press.

Devens, C. (1992). Countering Colonization: Native American Women and Great Lakes Mission, 1630-1900. Berkely: University of California Press.

Diamond, J. (2008). Vete, vapen \& virus - en kortsammanfattning av mänsklighetens historia under de senaste 13000 aren. Stockholm: Norstedt. 
Drake, J. D. (2004). Appropriating a Continent: Geographical Categories, Scientific Metaphors, and the Construction of Nationalism in British North America and Mexico. Journal of World History, 15(3). http://dx.doi.org/10.1353/jwh.2004.0031

Duara, P. (2001). The Discourse of Civilization and Pan-Asianism. Journal of World History, 12(1). http://dx.doi.org/10.1353/jwh.2001.0009

Duara, P. (2004). The Discourse of Civilization and Decolonization. Journal of World History, 15(1). http://dx.doi.org/10.1353/jwh.2004.0006

Eaton, R. M. \& Wagoner, P.B. (2014). Warfare on the Deccan Plateau, 1450-1600: A Military Revolution in Early Modern India?. Journal of World History, 25(1). http://dx.doi.org/10.1353/jwh.2014.0004

Eriksen, T.L. (2014). Imperier och imperialism. I Maria Sjöberg (Red.). En samtidig världshistoria. Lund: Studentlitteratur.

Fischer, G. V. (1992). Journal of Women's History Guide to Periodical Literature. Bloomington: Indiana University Press.

Frank, A. G. (1998). ReOrient: Global Economy in Asian Age. Berkely: University of California Press.

Garner, K. (2004). Global Feminism and Postwar Reconstruction: The World YWCA Visitation to Occupied Japan, 1947. Journal of World History, 15(2).

http://dx.doi.org/10.1353/jwh.2004.0019

Grimmer-Solem, E. (2005). German Social Science, Meiji Conservatism, and the Peculiarities of Japanese History. Journal of World History, 16(2).

http://dx.doi.org/10.1353/jwh.2005.0144

Hajnal, J. (1982). Two Kinds of Preindustrial Household Formation System, Population and Development Review, 8(3). http://dx.doi.org/10.2307/1972376

Hartman, H. (1976). Capitalism, patriarchy and job segregation by sex, Signs, 1(3). http://dx.doi.org/10.1086/493283

Hartman, M. S. (2004). The Household and the Making of History. A Subversive View of the Western Past. Cambridge: Cambridge University Press.

http://dx.doi.org/10.1017/CBO9780511818134

Hobson, J. M. (2007). Västerlandets österländska ursprung, Lund: Studentlitteratur.

Hughes-Warrington, M. (2011). Genders. I J. H. Bentley (Red.). The Oxford Handbook of World History. Oxford: Oxford University Press.

http://dx.doi.org/10.1093/oxfordhb/9780199235810.013.0012

Isom-Verhaaren, C. (2006). Royal French Women in the Ottoman Sultans' Harem: The Political Uses of Fabricated Accounts from the Sixteenth to the Twenty-first Century. Journal of World History, 17(2). http://dx.doi.org/10.1353/jwh.2006.0038

Keita, M. (2005). Africans and Asians: Historiography and the Long View of Global Interaction. Journal of World History, 16(1).

http://dx.doi.org/10.1353/jwh.2005.0138

Landes, J. B. (1988). Women and the Public Sphere. In the Age of the French Revolution. Cornell: Cornell University Press.

Lerner, G. (1986-1993). The Creation of Patriarchy, vols. 1, 2. New York: Oxford University Press.

Lindberg, A. (2004). Världshistoria med genusperspektiv. I Jarrick A. \& Johansson A. (Red.). Jorden runt igen - nya bidrag till en gammal globalhistoria. 25:e Nordiska historikermötet. Stockholm: Almqvist \& Wicksell International. 
Lynn II, J. A. (2008). Women, Armies, and Warfare in Early Modern Europe. Cambridge: Cambridge University Press.

Manning, P. (2003). Navigating World History: Historians create a global past. New York: Palgrave Macmillan. http://dx.doi.org/10.1057/9781403973856

Manz, B. F. (2002). Tamerlane's Career and Its Uses. Journal of World History, 13(1). http://dx.doi.org/10.1353/jwh.2002.0017

Marks, R. M. (2004). Den moderna världens ursprung. Lund: Arkiv Förlag/A-Z Förlag.

McCloskey, D. N. (2010). Bourgeois Dignity: Why Economics Can't Explain the Modern World. Chicago: University of Chicago Press.

http://dx.doi.org/10.7208/chicago/9780226556666.001.0001

McDowall, S. \& Gerritsen, A. (2012). Global China: Material Culture and Connections in World History. Journal of World History, 23(1).

McNeill, J. R. \& McNeill, W. H. (2006). Mänskliga nätverk. Världshistorien i ett nytt perspektiv. Stockholm: SNS Förlag.

Morris, I. (2010). Why the West Rules for Now. The Patterns of History and What They Reveal About the Future. London: Profile Books.

Müller, L. \& Rydén, G. (2009). Nationell, transnationell eller global historia? Replik till Stefan Eklöf Amirell och Rolf Torstendahl. Historisk tidskrift, 4.

$\mathrm{Ng}$, O.-C. (2003). The Epochal Concept of "Early Modernity" and the Intellectual History of Late Imperial China. Journal of World History, 14(1).

http://dx.doi.org/10.1353/jwh.2003.0013

Northrup, D. (2003). Free and Unfree Labor Migration, 1600-1900: An Introduction. Journal of World History, 14(2). http://dx.doi.org/10.1353/jwh.2003.0024

O'Brien, P. K. (2012). Fiscal and Financial Preconditions for the Formation of Developmental States in the West and the East from Conquest of Ceuta (1415) to the Opium War (1839). Journal of World History, 23(3). http://dx.doi.org/10.1353/jwh.2012.0090

Persson, F. (2014). Living in the House of Power: Women at the Early Modern Swedish Court. In Akkerman, N. \& Houben B. (Red.). The politics of female Households: Ladies in Waiting Across Early Modern Europe. Leiden: Brill.

Pomeranz, K. (2000). The Great Divergence: China, Europe, and the Making of the Modern World Economy. Princeton: Princeton University Press.

Pomeranz, K. (2007). Social History and World History: From Daily Life to Patterns of Change. Journal of World History, 18(1).

http://dx.doi.org/10.1353/jwh.2007.0006

Prestholdt, J. (2007). Similitude and Empire: On Comorian Strategies of Englishness. Journal of World History, 18(2). http://dx.doi.org/10.1353/jwh.2007.0015

Romaniello, M. P. (2014). Introduction. Journal of World History, 25(1). http://dx.doi.org/10.1353/jwh.2014.0002

Rubin, G. (1996). Traffic in Women. Notes on the "Political Economy" of Sex. I Scott, J. W. (Red.). Feminism \& History. Oxford: Oxford University Press. (1. Utgåva, 1975).

Sachsenmaier, D. (2007). World History as Ecumenical History?. Journal of World History 18(4). http://dx.doi.org/10.1353/jwh.2008.0002

Said, E. (1993). Orientalism. Stockholm: Ordfront.

Schaub, J.-F. (2013). Notes on some discontents in the historical narrative. I Maxine Berg (Red.). Writing the History of the Global. Challenges for the $21^{\text {st }}$ Century. Oxford: Oxford University Press. 
Schubert, A. (2012). Women Warriors and National Heroes: Agustina de Aragón and Her Indian Sisters. Journal of World History, 23(2).

http://dx.doi.org/10.1353/jwh.2012.0039

Scott, J. W. (1988). Gender: a Useful Category of Historical Analysis. I J. W. Scott, Gender and the Politics of History. New York: Columbia University Press.

Sennefelt, K. (2014). Den gamla ordningen och början på en ny, I Maria Sjöberg (Red.). En samtidig världshistoria. Lund: Studentlitteratur.

Sjöberg, M. (2001). Från kvinnohistoria till genushistoria. I Magnus Perlestam (Red). Genusperspektiv i historia. Metodövningar. Lund: Studentlitteratur.

Sjöberg, M. (2007). Förklara eller förstå. Meningen med och om historia. I Lennart Andersson Palm, L. A. \& Sjöberg, M. (Red.). Historia. Vänbok till Christer Winberg. Göteborg: Chalmers University of Technology.

Sjöberg, M. (2008). Kvinnor i fält, 1550-1850. Hedemora/Möklinta: Gidlund.

Sjöberg, M. (2011). Women in campaigns 1550-1850. Household and homosociality in the Swedish army. The History of the Family, 16(3).

http://dx.doi.org/10.1016/j.hisfam.2011.04.006

Sjöberg, M. (2012). Kritiska tankar om historia. Lund: Studentlitteratur.

Sjöberg, M. (2014). Haven och den europeiska kolonialismen. I Maria Sjöberg (Red.). En samtidig världshistoria. Lund: Studentlitteratur.

Smith, B. G. (Red.). (2004-2005). Women's history in global perspective, vol. 1-3, Illinois: University of Illinois Press.

Speidel, M. P. (2002). Berserks: A History of Indo-European "Mad Warriors. Journal of World History, 13(2). http://dx.doi.org/10.1353/jwh.2002.0054

Stearns, P. N. (2000). Gender in World History. New York: Routledge.

Stearns, P. N. (2007). Social History and World History: Prospects for Collaboration. Journal of World History, 18(1). http://dx.doi.org/10.1353/jwh.2007.0007

Strasser, U. \& Tinsman, H. (2010). It's a Man's World? World History Meets the History of Masculinity, in Latin American Studies, for instance. Journal of World History, 21(1).

Sutherland, H. (2007). The Problematic Authority of (World) History. Journal of World History, 18(4). http://dx.doi.org/10.1353/jwh.2008.0004

Torstendahl, R. (2009a). Idén om global historia och den transnationella trenden. Historisk tidskrift, (2).

Torstendahl, R. (2009b). Transnationell eller global. Slutreplik till Stefan Eklöf Amirell. Historisk tidskrift, (3).

Tvedt, T. (2012). Om metodologisk nasjonalisme og den kommunikative situasjonen - en kritikk og et alternativ. Historisk tidsskrift (norsk), 4.

Vivante, B. (1999). Women's Roles in Ancient Civilizations: A Reference Guide. Westport: Greenwood Press.

Washbrook, D. (2013). Problems in global history. I Maxine Berg (Red.). Writing the History of the Global. Challenges for the $21^{\text {st }}$ Century. Oxford: Oxford University Press.

Webb, J. L. A. (2005). Malaria and the Peopling of Early Tropical Africa. Journal of World History, 16(3). http://dx.doi.org/10.1353/jwh.2006.0011

Wiesner-Hanks, M. E. (2007). World History and the History of Women, Gender, and Sexuality. Journal of World History, 18(1).

http://dx.doi.org/10.1353/jwh.2007.0008 
Wiesner-Hanks, M. E. (2011). Gender in History. Global Perspectives. Chichester, West Sussex: Wiley-Blackwell.

Zaman, T. R. (2012). Visions of Juliana: A Portuguese Woman at the Court of the Mughals. Journal of World History, 23(4). http://dx.doi.org/10.1353/jwh.2012.0136

Zinsser, J. P. (2002). From Mexico to Copenhagen to Nairobi: The United Nations Decade for Women, 1975-1985. Journal of World History, 13(1). http://dx.doi.org/10.1353/jwh.2002.0028

Östenberg, I. (2009). Staging the World. Spoils, captives, and representations in the Roman triumphal procession. Oxford: Oxford University Press. http://dx.doi.org/10.1093/acprof:oso/9780199215973.001.0001 